\title{
Influence of Space on Interactivity Aspects in Pre-School Facilities in the City of Niš, Serbia: Case Study Analysis
}

\author{
Aleksandar MILOJKOVIĆ, Jasmina TAMBURIĆ, Danica STANKOVIĆ, Milan BRZAKOVIĆ
}

\begin{abstract}
Creating a healthy environment for pre-school children in kindergartens is about providing fundamental spatial comfort, a comprehensive program and conceptual adaptation of both inner and outer space. The aim of this study was to investigate the interactivity aspect of pre-school children facilities in Nišs, Serbia, with the emphasis on a space as its determinant. As the most important aspects of spatial interactivity, which should be improved, this research recognized open spaces and space for play, improvement of existing classrooms and multifunctional spaces. A horizontal (creating of activity pockets using mobile elements and custom-made furniture) and vertical (introduction of galleries for sleeping) spatial differentiation of existing playrooms is recommended as central activity. Our results imply that a transformation of existing multipurpose spaces into an extension of the surrounding playrooms could contribute to the space quality, and result in diverse learning environment oriented toward active and self-learning
\end{abstract}

Keywords: children's needs; interactivity; kindergarten design; psycho-social development; space

\section{INTRODUCTION}

Relevant studies exploring the interrelation of interior space and children's psychological development are largely aimed at determining the importance and effects that space has on a child's growth. However, pedagogical innovations in education are the foundation on which the need for space transformation should be interpreted. The issue of early education and its importance for society are permanent reasons for detecting systemic transformations so that children could achieve better results later in life. Pre-school age should be recognized as a crucial privileged stage of life which requires considerable investment and constant system improvements of the early education, characterized by openness, availability and financial benefits.

A number of studies have revealed that experiences gained during preschool years have a great impact on the subsequent accomplishments of an individual, and that kindergartens have a major influence on child development since these are places where children spend most of their preschool time [1]. Various research on the topic of children's development confirms that "children learn what they live" [2]. The idea of oneself, others and the world that children develop in kindergarten depends on what kind of world is created in the pre-school facility. Therefore, this extremely important developmental period must be used by the society, local community and parents to actively encourage the improvement of the intellectual potential of each and every child.

\section{THE MODERN PRESCHOOL EDUCATION PREMISES}

The educational system is the most important element of the developmental and life infrastructure of every individual, society and country [3]. High-quality education contributes to a child's intellectual, social, physical and emotional development [4]. Current pedagogical tendencies are moving in the direction of opening the educational system and accepting the modern educational methods. Colić [5] claims that children need to be given the opportunity to gain life experience, in accordance with their age and individual possibilities, on life matters which are important for them, so that they can solve the majority of problems independently and enrich their experiences. This opportunity will enable them to gain knowledge and skills which would be applicable in future real life situations, not only at school.

It was already determined that the results of the application of high-quality preschool programs are better for the cognitive, social and emotional development of children. Maxwell and Evans have underlined the importance of pre-school education facilities by designating them as a "home away from home", which, without doubt, has a major space design implications [6].

The physical environment and the architectural organization of the educational space also proved to be important contextual factors for the realization of the pedagogical process [7]. Certain researchers examined the physical elements in space - the effect of colours and shapes on children's development. The extensive research by Marilyn A. Read named "Creative education", highlights children's need to visualize space, especially by using circle and spherical shapes. Children respond positively to these design elements and principles [8]. Moore [9] recalls that all major theories like those of Piaget, Montessori and Warner emphasize the interaction of the child with his or her environment as the basis of development. Consequently, it is clear that the physical environment in which children develop various relationships with the social environment represents one of the essential frameworks for the mapping of the qualitative properties of kindergarten.

The first six years of life is the most sensitive and vital period for the emotional, mental and social development of every child. According to the psychologist Erik Erikson, personality development takes place in stages, whereas childhood goes through four essential stages, namely the trust stage, autonomy stage, the initiative stage and responsibility stage. The first three stages are related to the period of early childhood which the child usually spends in a preschool facility. This period is of a paramount importance for the psycho-social personality development and includes certain fundamental and developmental needs of children [10]. Children's freedom of thought and play, the wish for alone time and isolation, as well as different 
habits are only some of the needs which should be provided. One can identify children's mental and physical needs, emotional states, social aspirations and influence of social environment by observing child's activities, actions and play [11].

\subsection{Instruction Methods in Early Education}

The intellectual potential of children must be continuously stimulated in order to develop various personal abilities. If only one of the brain functions is neglected, there is a chance of developmental disabilities in children. Children need to be provided with a healthy and stimulating social and physical environment [3].

There are two basic models of early education in current pedagogical practice - the constructivist model and the instructional model of the curriculum. Within the constructivist model (interactive learning), the child is engaged through self-determined activities and explores spontaneously by playing with other children. Within the instructional model, the educator comes up with tasks and has the role of a guide and instructor. In modern practice, the constructivist model of interactive learning has proven itself as a more efficient in terms of functional knowledge in later stages of school.

Interactive instruction involves a comprehensive methodological approach in the initial stage of socialization, education and instruction. According to Popovic [12] the basic purpose of the interactive method is the shift of focus from the educator to children, teaching children to learn together, to work on goal-accomplishment together through play, learn how to process content, apply what has been learned and value processes. In that manner, education can be connected to real life situations and context, while the institution itself becomes a set of different places where a child can experience and learn something [5].

\subsection{The Role of Space in Interactive Instruction}

The physical environment is a critical part of any child care program and has an important role in children's behaviour and development [6]. As Nicholson [13] points out, "children discover the world through their senses." Thus, "by nourishing senses and emotions, architecture plays an important role in child development" [14]. Children show better knowledge and motivation in further education when they learn interactively with other children in a stimulating environment. Child's capacities and abilities, in terms of preschool environment impact, can be characterized as an opportunity to have active and efficient relation with the environment [11]. Immediate physical surrounding should primarily support pedagogical activities [15]. Research by Moore [16] has confirmed that the quality of designed space of a preschool facility, viewed as physical environment, has an effect on children's development, especially their cognitive development and social behaviour. The concept of interactive space is based on the idea of opening up day cares space and establishing a relationship between the inner and outer space. The results of studies performed in Sweden by Brodin and Lindstrand [17], suggest the importance of children's interaction with nature and environment. It was recognized that some places are more highly valued by children, which is related to their need for privacy, control and security. The examples of such spaces are contained spaces, like attics, boxes, small rooms, as well as places with vegetation, sun or water, and spaces from which children can see but cannot be seen - secret places [17].

Interactive space is a flexible, multi-purpose space in which various activities and programs can be carried out. Such a space should essentially meet the optimal spatial capacity and volume based on the number of children per group, provide warmth and visual comfort, and be adequately equipped and furnished. A fewer number of children per group is linked to an increased interaction, individualization and better accomplishment. The primary function of the physical context of interactive space is to create possibilities and conditions for proper and healthy development, which can play a vital role in children's real life experience and consequently, benefit the whole society [18]. The day cares space should provide safety, freedom of movement, availability of educational and other equipment, easy use, complexity, stimulation, identity and privacy [19]. The modern concept of architectural organization of interior space is a multifunctional, creative, and pre-planned space, designed so that children can fulfil their needs undisturbed - a space where they can explore and develop their personal preferences and affinities [11, $20]$.

If a day-care space is regarded as the central space where children spend most of their day, then such space should stimulate numerous fundamental and functional needs of children. All additional activities within educational programs can create needs for the introduction of additional architectural amenities. According to the interactive method which deals with the early personality development, children's behaviour and social interaction require a special, stimulating space where all program activities can unfold without disturbance [19]. The organization and volume of the given space, as well as the spatial concept, colours and form, should therefore contribute to the better space quality. Spatial concept refers to the organization of space, which is reflected in an appropriate distribution of functional, optimally sized and adequately equipped units. Such units are the foundation of high-quality future use [11].

\subsection{Types of Interactivity in Relation to Space}

When space is viewed as the environment in which children spend most of their time, there are two basic types of interactivity - namely, interactivity in relation to outer and inner space.

Outer space is an important segment of interactivity, as it offers various possibilities for achieving the expansion or connection of inner space with the surrounding communication system. Kindergarten facilities should have an adequate location protected from noise and pollution. The exterior design of kindergartens should be attractive, shaped and dimensioned in an appropriate manner for preschool children. The kindergarten yard should provide an optimal space for education, outdoor play and activities.

Inner Space is defined by its specific form and adequate equipment. The overall aesthetic effect of the space is created in interaction of the elements of line, shape, form, pattern, texture, scale, light, and colour with the principles of proportion, balance, rhythm, contrast, 
emphasis, and harmony [8]. At the same time, the space designed for children must be dimensioned, shaped and painted with care, having in mind its influence on children. A quality design aims to create a classroom that is highly functional, aesthetically attractive, age-appropriate, childdirected, and teacher-supported. A well-designed group care environment promotes children's individual and social development.

Kindergarten facilities most commonly contain only the ground floor and are planned so that they can be extended or provided with additional necessary amenities. Based on the functional solution of the interior, there are four architectural concepts:

1) Open roof plans - The common denominator is an open system of education with an appropriate environment and inclusion of children into interaction with the environment. This architectural concept provides an interesting layout and interface between inside and outside (Fig. 1). It invites to diverse play - from quiet and sensuous activities to the more physically challenging. The building is a workshop where every day is a new chapter in the curious mind of a child.

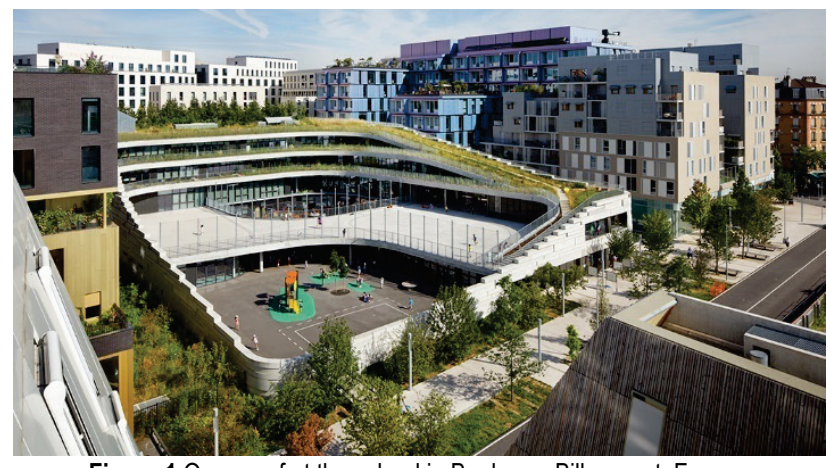

Figure 1 Open roof at the school in Boulogne-Billancourt, France.

Source: http://www.larchitecturedaujourdhui.fr/ramping-up-the-green-in-oneboulogne-school-chartier-dalix-chose-to-integrate-biodiversity/?lang=en

2) Playrooms - Creative space whose design sparks children's imagination and creativity. Dominant factors include form, colour and material, and space size (Fig. 2). Such a concept can be implemented in kindergartens which are situated in the city centre, when the open roof plan would not be applicable due to large levels of pollution. In such examples, it is necessary to optimize the inner space, which would satisfy the needs of children. The main idea is to separate peaceful zones (for sleeping) from the active zones i.e. playrooms. For classrooms designed for toddlers, the colour is blue (relaxation, the sea, the world of dreams); classrooms for children between 1 and 2 are painted orange (psychomotor stimulation, activity); for children between 2 and 3 years of age, the chosen colour is green (contact with nature).

3) Topic-based segmented organization of space Workshops - A concept which consists of segmented functional zones, passive and active (playrooms and educational classrooms, respectively), so that children can thematically change the space where they stay in a single day. It functions as an open system where the child does not remain in a fixed position. Functional zones are clearly divided into peaceful and active-educational. This spatial concept is applicable in facilities which can provide an adequate number of rooms (thematic work rooms), which would need to have an immediate connection to the central gathering unit. The central unit can have the characteristics of multi-purpose space. The work room system is appropriate for children aged between 3 and 6 which is why it can only be partially applied to most existing objects.
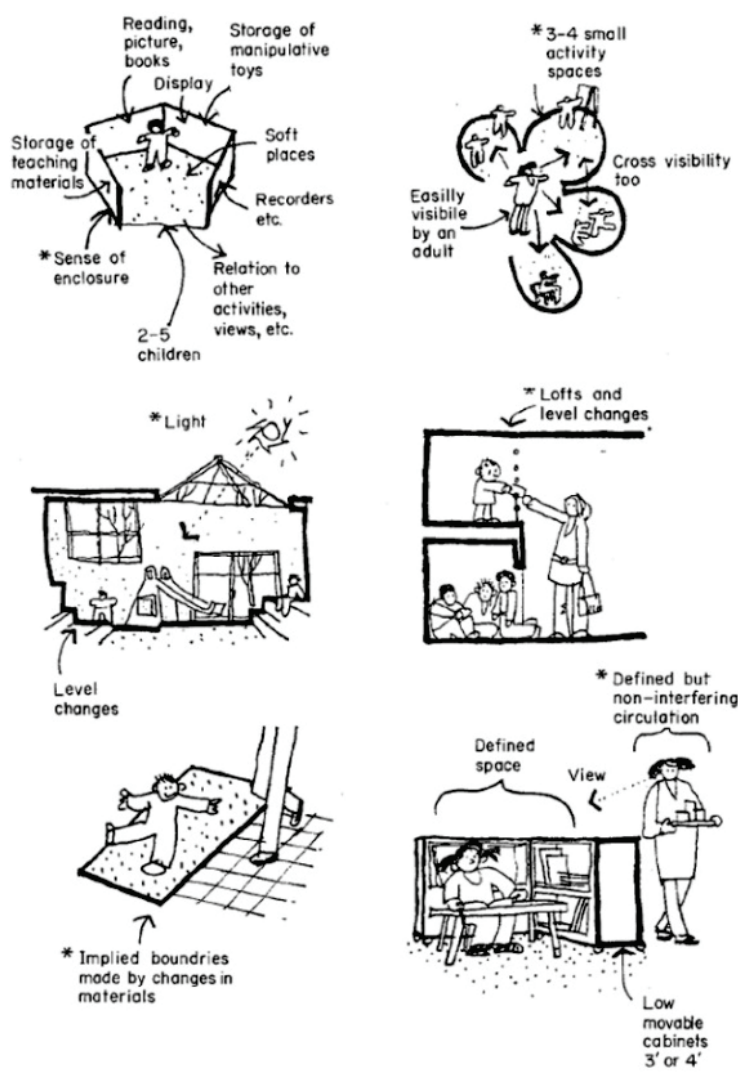

Figure 2 Ways to spatially define behaviour settings in kindergarten playrooms. Source: [23]

4) Multipurpose space - should create a free active zone for all ages, and can be used for various purposes (as work rooms, play rooms etc.). A multipurpose space, which unites the aforementioned architectural concepts (playrooms, workshops), is frequently equipped with mobile elements (furniture, toys, screens) in order to be used primarily as a place for free activities or for various performances and events. Every kindergarten should contain at least one multipurpose space. Such a space can have arbitrary dimensions, depending on the estimate of architects. Multipurpose space can be viewed as an enclosed playground and is often connected to the open space in order to enable a smooth transfer of activities happening inside to the outside, open space.

\section{ANALYSIS OF THE LEVEL OF INTERACTIVITYIN PRE- SCHOOL FACILITIES IN THE CITY OF NIŠ - CASE STUDY RESULTS}

The current system in Serbia consists of a network of 159 public preschool facilities with 2,384 buildings whose founders are local municipalities, as well as 60 private facilities [3]. In the city of Niš, which has a population of 300,000 people, there are 20 kindergartens, predominantly built during the 1970's and 1980's [20]. This research covers all the kindergartens in the area of the city of Niš. The spatial problems of the existing kindergarten facilities, prescribed norms, and the demands presented by sociopedagogical needs were reviewed, and statistical analysis of the collected data was performed for all kindergarten facilities in the city of Niš. 
The research consists of three parts. Each of these parts is dedicated to some of the crucial aspects of interactive space, and it investigates interactivity of existing spaces, and the possibilities for improvements of these aspects. The consisting parts of the research are:

1) Outer space analysis - with the main focus on the connection of inner space with the surrounding open spaces (open roof);

2) Playrooms analysis - where the elemental spatial features (size, shape, height) and aspects of interactivity are investigated;
3) Multipurpose spaces analysis - focussed on the spatial features of current multipurpose spaces and possibility for their transformation.

The conducted research has the aim of determining whether the current kindergartens could adopt the principles of interactive space. By revealing which of these principle is appropriate to apply to which particular kindergarten, it becomes possible to define models of their introduction. Recommendations for further interventions and models of introduction are presented in the discussion section.

Table 1 Outer space analysis results

\begin{tabular}{|c|c|c|c|c|c|c|c|c|c|c|}
\hline \multicolumn{11}{|c|}{ Outer space } \\
\hline & \multirow[b]{3}{*}{ Kindergarten } & \multicolumn{5}{|c|}{ Courtyard } & \multicolumn{4}{|c|}{ Kindergarten building } \\
\hline & & \multirow{2}{*}{ 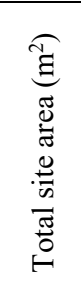 } & \multirow{2}{*}{ 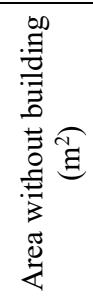 } & \multirow{2}{*}{ 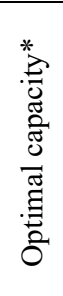 } & \multirow[b]{2}{*}{$\begin{array}{l}\frac{\partial}{\exists} \\
\frac{\pi}{0} \\
\text { సี }\end{array}$} & \multirow{2}{*}{ 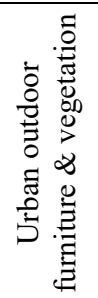 } & \multirow{2}{*}{ 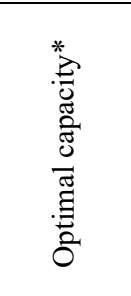 } & \multirow{2}{*}{ 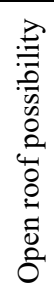 } & \multicolumn{2}{|c|}{ Playrooms } \\
\hline & & & & & & & & & 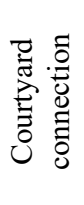 & 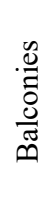 \\
\hline 1. & Bajka & 4875 & 3960 & 396 & $22.0-30.5$ & ++ & $130-180$ & 1 & $3 / 3$ & $5 / 5$ \\
\hline 2. & Bambi & 4882 & 3809 & 381 & $16.9-23.8$ & ++ & $160-225$ & + & $4 / 4$ & $3 / 5$ \\
\hline 3. & Bubamara & 3570 & 2622 & 262 & $16.9-23.4$ & ++ & $112-155$ & +- & $8 / 8$ & 1 \\
\hline 4. & Crvenkapa & 4155 & 3218 & 322 & $16.0-22.3$ & ++ & $144-201$ & + & $6 / 6$ & $3 / 3$ \\
\hline 5. & Cvetić & 6573 & 5663 & 566 & $21.9-30.8$ & -- & $184-258$ & 1 & $5 / 5$ & $5 / 5$ \\
\hline 6. & Cvrčak & 4875 & 3960 & 396 & $23.0-32.2$ & +-+ & $123-172$ & I & $5 / 5$ & $3 / 3$ \\
\hline 7. & Kolibri & 4481 & 3647 & 365 & $20.4-28.5$ & ++ & $128-179$ & 1 & $4 / 4$ & $5 / 5$ \\
\hline 8. & Lane & 1108 & 575 & 57 & $6.8-9.6$ & -- & $60-84$ & +- & $4 / 4$ & 1 \\
\hline 9. & Leptirić & 6644 & 4920 & 492 & $19.4-27.2$ & ++ & $181-254$ & + & $6 / 6$ & $4 / 4$ \\
\hline 10. & Maslačak & 2665 & 1905 & 190 & $12.3-17.3$ & ++ & $110-155$ & + & $3 / 3$ & $4 / 4$ \\
\hline 11. & Neven & 2056 & 1223 & 122 & $6.3-8.8$ & -+ & $138-194$ & + & $3 / 3$ & $3 / 3$ \\
\hline 12. & Palčić & 2982 & 2344 & 234 & $16.7-23.4$ & ++ & $100-140$ & 1 & $0 / 4$ & $6 / 9$ \\
\hline 13. & Pepeljuga & 7555 & 6660 & 666 & $73.2-102$ & ++ & $65-91$ & 1 & $4 / 4$ & $4 / 4$ \\
\hline 14. & Petar Pan & 4238 & 3378 & 338 & $16.8-23.5$ & ++ & $144-201$ & 1 & $4 / 4$ & $0 / 4$ \\
\hline 15. & Pinokio & 3367 & 2283 & 228 & $11.6-16.2$ & ++ & $141-197$ & 1 & $4 / 4$ & $3 / 3$ \\
\hline 16. & Plavi čuperak & 1543 & 735 & 73 & $4.4-6.2$ & ++ & $119-166$ & 1 & $3 / 3$ & $1 / 4$ \\
\hline 17. & Slavuj & 2992 & 2206 & 221 & $21.2-29.8$ & +- & $74-104$ & I & $2 / 8$ & $0 / 3$ \\
\hline 18. & Svitac & 1654 & 1260 & 126 & $16.1-23.3$ & +- & $54-78$ & 1 & $0 / 2$ & I \\
\hline 19. & Vilin grad & 5869 & 5041 & 504 & $24.0-33.6$ & +- & $150-210$ & 1 & $4 / 4$ & $0 / 4$ \\
\hline 20. & Zvončić & 4260 & 3443 & 344 & $16.7-23.4$ & ++ & $147-206$ & 1 & $4 / 4$ & $0 / 4$ \\
\hline
\end{tabular}

\subsection{Outer Space Analysis}

The first part of the research is mainly focused on the characteristics of outer space and the established relationship between the inner and outer space (Tab. 1).

Outer space analysis starts with the review of basic spatial parameters: size of the location, size of the courtyard (without the area under the building) and optimal capacity of the courtyard based on official minimum area requirements per child [22]. Furthermore, according to the optimal capacity of kindergarten facility (calculated in the next subchapter concerned with playroom analysis) actual courtyard area per child is calculated. The obtained data clearly indicate that the majority of analysed kindergartens have very large courtyards with more than enough space for play and greenery, with only 3 cases of overload of the plot capacity with the building that is located there. The possibility of applying the principle of open green roofs to serve as compensation in cases where the size of the existing courtyard is insufficient was also analysed. In 2 cases of overloading the site there is a real possibility of transforming the roof into a park space. Next part of the analysis is concentrated on the courtyard and the presence of diverse vegetation and appropriate urban outdoor furniture. The relation between the inner and outer space is evaluated through analysis of the connection of playrooms with outer spaces (courtyards, atriums, and terraces). According to the results, 125 out of 160 analysed playrooms have a direct connection with outer spaces. Furthermore, when it comes to the playrooms located on the ground floor, 76 out of 88 playrooms have direct physical connection with the courtyard; while it should be noticed that majority of playrooms located on upper floors are dedicated to the toddlers that spend less time outdoors. Thus, it is safe to conclude that vast majority of analysed kindergartens show high level of interactivity between inner and outer space. 
Table 2 Playrooms analysis results

\begin{tabular}{|c|c|c|c|c|c|c|c|c|c|c|c|}
\hline \multicolumn{12}{|c|}{ Playrooms } \\
\hline & Kindergarten & 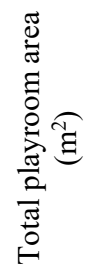 & 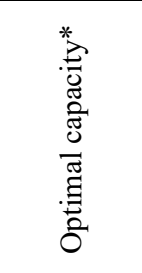 & 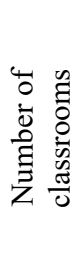 & 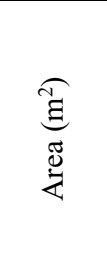 & 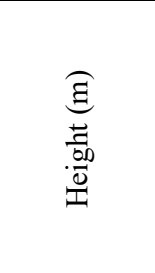 & 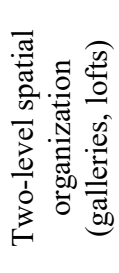 & 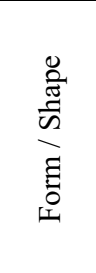 & 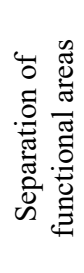 & 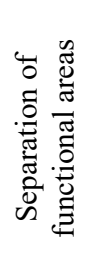 & 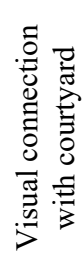 \\
\hline 1. & Bajka* & 459.7 & $130-180$ & 8 & $35-70$ & 3.00 & - & $\mathrm{P}$ & $4 / 8$ & $5 / 8$ & $8 / 8$ \\
\hline 2. & Bambi & 562 & $160-225$ & 9 & $45-60$ & 2.95 & - & $\mathrm{Ra}$ & 1 & $6 / 9$ & $9 / 9$ \\
\hline 3. & Bubamara & 392.1 & $112-155$ & 8 & $30-57$ & 3.00 & - & $\mathrm{Ra}, \mathrm{Rb}$ & 1 & $3 / 8$ & $8 / 8$ \\
\hline 4. & Crvenkapa & 504 & $144-201$ & 9 & $48-60$ & 2.80 & - & $\mathrm{H}$ & 1 & 1 & $7 / 9$ \\
\hline 5. & Cvetić & 645.7 & $184-258$ & 10 & 64 & $2.95-3.30$ & + & $\mathrm{H}$ & / & $10 / 10$ & $10 / 10$ \\
\hline 6. & Cvrčak & 431 & $123-172$ & 8 & 70 & 3.15 & exist & $\mathrm{Rb}$ & $2 / 8$ & $8 / 8$ & $8 / 8$ \\
\hline 7. & Kolibri* & 448.2 & $128-179$ & 9 & $34-74$ & 2.90 & - & $\mathrm{P}$ & $6 / 9$ & $6 / 9$ & $5 / 9 *$ \\
\hline 8. & Lane & 209.5 & $60-84$ & 4 & $46-64$ & $2.50-2.60$ & - & $\mathrm{Ra}$ & $3 / 4$ & $3 / 4$ & 1 \\
\hline 9. & Leptirić & 635.5 & $181-254$ & 10 & $45-64$ & 2.90 & - & $\mathrm{P}$ & $10 / 10$ & 1 & $10 / 10$ \\
\hline 10. & Maslačak & 389 & $110-155$ & 7 & $40-61$ & 3.00 & - & $\mathrm{Rb}$ & 1 & $7 / 7$ & $6 / 7$ \\
\hline 11. & Neven & 486.1 & $138-194$ & 6 & $50-89$ & 3.10 & & $\mathrm{Rb}, \mathrm{L}$ & $4 / 6$ & $6 / 6$ & $4 / 6$ \\
\hline 12. & Palčić & 350.8 & $100-140$ & 13 & $15-35$ & 3.00 & - & $\mathrm{Rb}$ & $1 / 13$ & $2 / 13$ & $10 / 13$ \\
\hline 13. & Pepeljuga & 228 & $65-91$ & 8 & 57 & 2.50 & - & $\mathrm{P}$ & $8 / 8$ & 1 & $8 / 8$ \\
\hline 14. & Petar Pan** & 504 & $144-201$ & 8 & 70 & 3.20 & + & $\mathrm{Rb}$ & 1 & $8 / 8$ & $8 / 8$ \\
\hline 15. & Pinokio & 494.2 & $141-197$ & 7 & $45-70$ & 3.28 & exist & $\mathrm{L}$ & $5 / 7$ & $6 / 7$ & $7 / 7$ \\
\hline 16. & Plavi čuperak* & 417 & $119-166$ & 7 & 70 & 3.25 & + & $\mathrm{P}$ & $5 / 7$ & 1 & $7 / 7$ \\
\hline 17. & Slavuj & 260 & $74-104$ & 11 & $30-54$ & 2.85 & - & $\mathrm{Ra}, \mathrm{Rb}$ & 1 & 1 & $8 / 11$ \\
\hline 18. & Svitac & 194.4 & $54-78$ & 4 & 48 & $3.40-4.80$ & + & $\mathrm{Ra}$ & 1 & 1 & $2 / 2$ \\
\hline 19. & Vilin $\operatorname{grad}^{* *}$ & 524.7 & $150-210$ & 8 & 70 & 2.95 & - & $\mathrm{Rb}$ & 1 & $8 / 8$ & $8 / 8$ \\
\hline 20. & Zvončić** & 516.4 & $147-206$ & 8 & 70 & 3.00 & - & $\mathrm{Rb}$ & 1 & $8 / 8$ & $8 / 8$ \\
\hline
\end{tabular}

Table 3 Multipurpose space analysis results

\begin{tabular}{|c|c|c|c|c|c|c|c|c|c|c|c|}
\hline \multicolumn{12}{|c|}{ Multipurpose space } \\
\hline & \multirow[b]{2}{*}{ Kindergarten } & \multirow{2}{*}{ 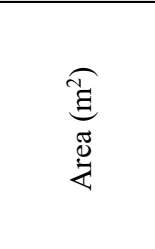 } & \multirow{2}{*}{ 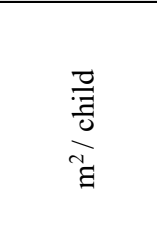 } & \multirow{2}{*}{ 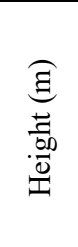 } & \multirow{2}{*}{ 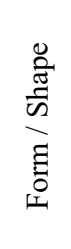 } & \multicolumn{2}{|c|}{$\begin{array}{l}\text { Connection } \\
\text { with }\end{array}$} & \multirow{2}{*}{ 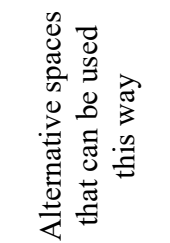 } & \multirow{2}{*}{ 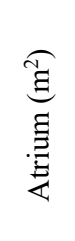 } & \multicolumn{2}{|c|}{ Upgraded } \\
\hline & & & & & & 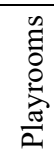 & 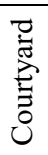 & & & 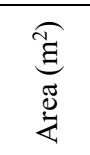 & 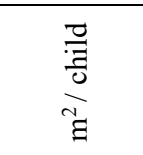 \\
\hline 1. & Bajka & 55.7 & $0.3-0.4$ & 3.00 & $\mathrm{R}$ & + & + & $100+107.5$ & I & 263.2 & $1.46-2.02$ \\
\hline 2. & Bambi & 98.1 & $0.43-0.61$ & 2.95 & $\mathrm{R}$ & +- & + & $91.2+94.4$ & 37.1 & 283.7 & $1.26-1.77$ \\
\hline 3. & Bubamara & 1 & 1 & 1 & 1 & / & 1 & 95.5 & 1 & 95.5 & $0.62-0.85$ \\
\hline 4. & Crvenkapa & 73.1 & $0.36-0.51$ & 2.80 & $\mathrm{H} / \mathrm{P}$ & - & - & 75.4 & 41.9 & 148.5 & $0.74-1.03$ \\
\hline 5. & Cvetić & 1 & 1 & 1 & 1 & 1 & 1 & $104.5+93.2$ & 1 & 197.7 & $0.77-1.07$ \\
\hline 6. & Cvrčak & 180 & $1.04-1.46$ & 3.00 & $\mathrm{R}$ & + & + & 1 & 1 & / & 1 \\
\hline 7. & Kolibri & 59 & $0.32-0.46$ & 2.90 & $\mathrm{R}$ & + & + & $100+102.7$ & 1 & 261.7 & $1.46-2.04$ \\
\hline 8. & Lane & l & 1 & 1 & 1 & 1 & 1 & 23.1 & 12.4 & 23.1 & $0.28-0.38$ \\
\hline 9. & Leptirić & 97.6 & $0.38-0.53$ & 2.90 & $\mathrm{R}$ & + & + & $119.7+59.5$ & 84.6 & 276.8 & $1.09-1.53$ \\
\hline 10. & Maslačak & 78.7 & $0.51-0.71$ & 3.00 & $\mathrm{R}$ & + & + & $55.2+56.6$ & 1 & 190.5 & $1.23-1.73$ \\
\hline 11. & Neven & $40.5+61.2$ & $0.52-0.74$ & 3.10 & $\mathrm{R}$ & + & - & 1 & 1 & 1 & 1 \\
\hline 12. & Palčić & 80.4 & $0.57-0.80$ & 3.00 & $\mathrm{R}$ & - & + & 24.45 & 1 & 104.8 & $0.75-1.05$ \\
\hline 13. & Pepeljuga & 96.4 & $1.06-1.48$ & 2.50 & $\mathrm{R}$ & + & - & 37.3 & 1 & 133.7 & $1.47-2.06$ \\
\hline 14. & Petar Pan & 100 & $0.50-0.70$ & 3.20 & $\mathrm{R}$ & + & + & 1 & 1 & 1 & 1 \\
\hline 15. & Pinokio & $191.1+85$ & $1.40-1.96$ & 3.28 & $\mathrm{R}$ & + & + & 1 & 1 & 1 & 1 \\
\hline 16. & Plavi čuperak & 58 & $0.35-0.49$ & 3.25 & $\mathrm{R}$ & + & + & $100+105.4$ & 1 & 263.4 & $1.57-2.21$ \\
\hline 17. & Slavuj & 42.4 & $0.41-0.57$ & 2.85 & $\mathrm{R}$ & + & - & 1 & 1 & / & 1 \\
\hline 18. & Svitac & 69.3 & $1.78-2.57$ & 3.8 & $\mathrm{R}$ & + & + & 1 & 1 & / & 1 \\
\hline 19. & Vilin grad & 100 & $0.48-0.67$ & 2.95 & $\mathrm{R}$ & + & + & 1 & 1 & 1 & 1 \\
\hline 20. & Zvončić & 100 & $0.49-0.68$ & 3.1 & $\mathrm{R}$ & + & + & 1 & 1 & 1 & 1 \\
\hline
\end{tabular}

\subsection{Playrooms Analysis}

The second part of the research is focused on playrooms within all pre-school facilities in the city of Niš (Tab. 2). It was started with the analysis of the basic spatial characteristics, such as: size, clear height, form and optimal capacity of each kindergarten, in order to determine the more complex parameters which indicate the current space interactivity, as well as the possibilities for transformation and improvement of current condition [21]. Furthermore, optimal capacity of each kindergarten facility is calculated, on the basis of its total playroom area and recommended minimum area per child. Forms of playrooms are 
predominantly orthogonal, with four different typologies recognized in this research: polygonal, rectangular and hexagonal. Next part of the analysis is concerned with more complex parameters that indicate current interactivity of space, as well as the possibilities for transformation and improvement of current condition. A more detailed analysis of the spatial capacities and the organization of existing classrooms clearly points to the possibility of introducing gallery spaces into existing classrooms, as well as additional spatial differentiations and creation of activity pockets - smaller spaces partially surrounded with walls or equipment - in already existing space.

\subsection{Multipurpose Space Analysis}

Multifunctional spaces were analysed in the last part of the research (Tab. 3). Based on the size of the existing multifunctional spaces and previously determined optimal capacities of the kindergarten buildings, the areas are calculated per user. Further basic features investigated in this part of the research are clear height and shape of these spaces. The analysis of the spatial/physical relation these spaces have toward outer spaces and playrooms is the central part of the research, while the last part reveals the possible outcomes of the recommended interventions. During the research, it was noticed that more than a half of analysed kindergartens possess some alternative space which could be used for the enlargement of current multipurpose spaces. In the last part of this analysis, the surface areas that could be used to extend the multifunctional space were investigated, as well as average data after possible interventions on these objects.

\section{DISCUSSION}

The results of the research clearly indicate the positive and negative aspects of the current situation. Based on these results, it is possible to recognize critical points and define models of the intervention which would improve current interactivity of space. As the most important aspects of spatial interactivity which should be improved, this research recognized: open spaces and space for play, improvement of existing classrooms and multifunctional spaces.

As it was already stated, the results obtained in this research clearly indicate that the majority of analysed kindergartens have very large courtyards with more than enough space for all the kindergartens outdoor activities. Kindergartens Lane, Neven and Plavi čuperak are only exceptions. In these cases size of the courtyard does not meet the minimal area requirement for the kindergarten facilities built on them. However, in cases of Lane, and especially Neven, it is possible to convert existing roofs into extension of the courtyard, and improve the current condition.

When it comes to classrooms in kindergartens, the results point to the spaces of the usual orthogonal forms (with just two exceptions, kindergartens Crvenkapa and Cvetić) that mostly meet the standards for size and height. However, very few principles of spatial interactivity are integrated in these solutions. The two-level organization of the space is present in only 2 kindergartens, and in only 4 kindergartens the bright height of the classroom allows for conversion to such a place. Adaptation of the existing oneroom space into two-sided, with the use of different bright altitudes that occurs with a sloping roof, is possible in the kindergarten Cvetić.

Analysis of the spatial differentiation of existing playrooms showed that this principle is much more present in local kindergartens. Exactly half of the analysed kindergartens have at least one playroom in which this principle is already present, while the minor interventions (that involve changes in the organization of space and the design of equipment for a specific space) it is possible to integrate this principle into another 7 kindergartens (Fig. $3)$.

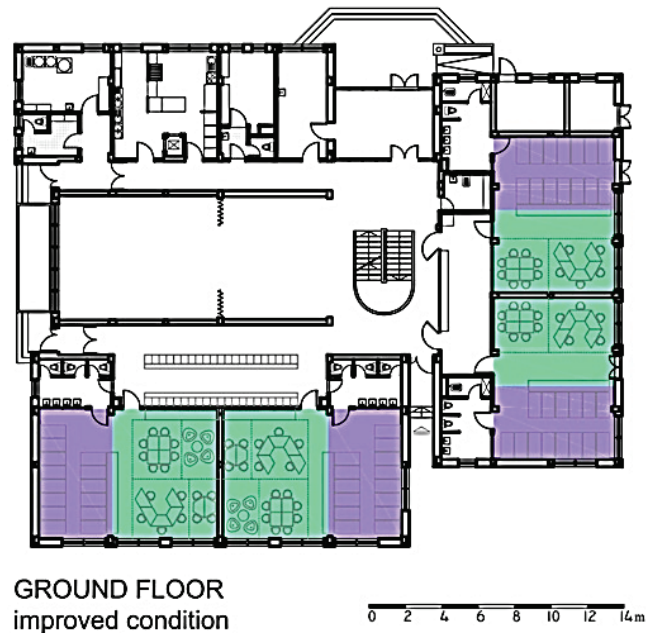

Figure 3 Spatial differentiation of existing playrooms in kindergartens Petar Pan, Vilin grad and Zvončić. Source: author

One of the notable design trends in the kindergarten architecture is the avoidance of complex and closed system of corridors and their replacement with central multipurpose space of an open spatial configuration, which represents the core of every kindergarten and plays the role of the main square in the city. Improvement of existing multifunctional spaces is possible through their enlargement. The enlargement of multipurpose spaces can result in better positions in relation to outer space and playrooms. The research has shown that a majority of the kindergartens has proper size of their multifunctional spaces. In addition, most of these spaces have a very favourable position in the building, visually connected with the courtyard and in the immediate vicinity of playrooms. However, most kindergartens have additional spaces that can be used as extensions of existing multifunctional spaces; with minor intervention (demolition of partition walls) it is possible to further improve the situation. In the case of the Crvenkapa kindergarten, the expansion of the multifunctional space at the expense of the entrance hall, in addition to the additional surface, introduces a direct connection with the open space (atrium) and improves the connection with the playrooms (Fig. 4). A different example is the typical objects of the Bajka kindergarten, Kolibri and Plavi čuperak, where multifunctional spaces already have a direct connection with the yard, but their enlargement improves the connection with the playrooms (Fig. 5). These transformations should turn existing multipurpose spaces into an extension of the surrounding playrooms. Furthermore, these changes should result in diverse learning environment oriented toward active and selflearning. 

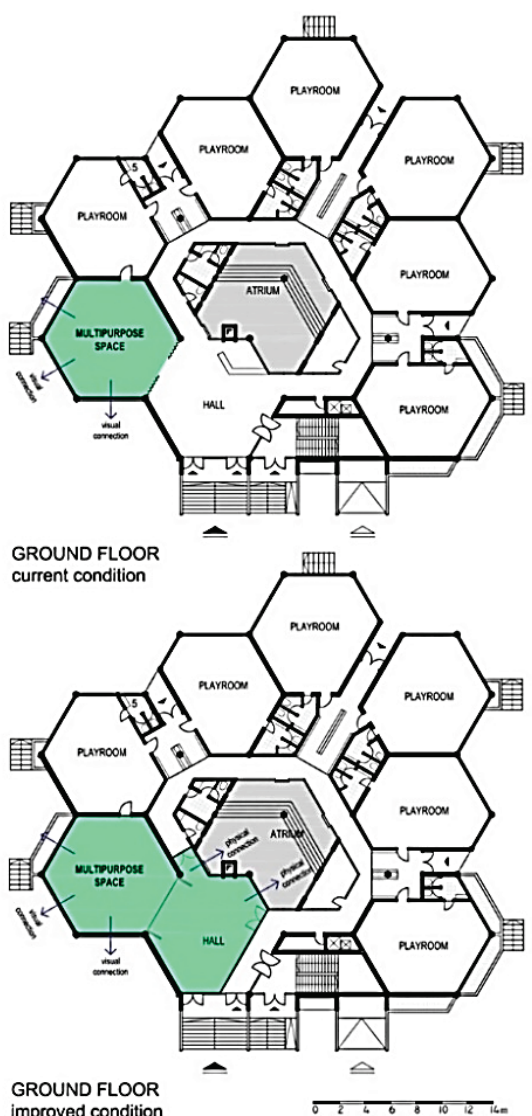
GROUND FLOOR
improved condition

Figure 4 Multipurpose space enlargement in Crvenkapa kindergarten. Source: author

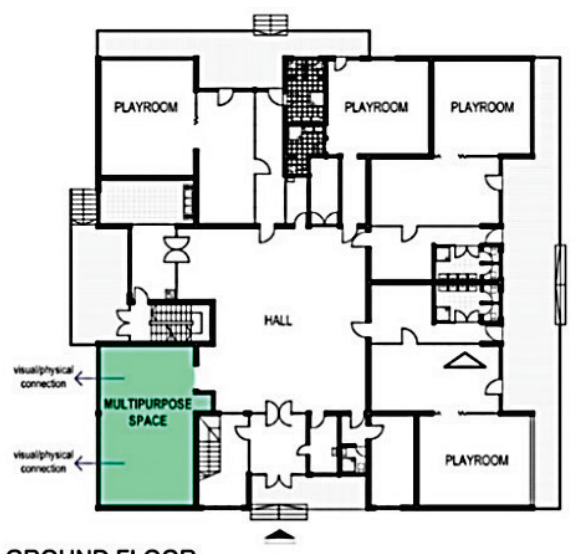

GROUND FLOOR current condition

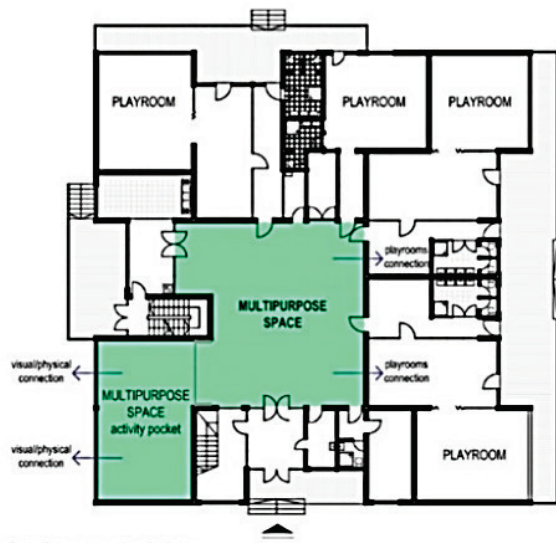

GROUND FLOOR improved condition

Figure 5 Multipurpose space transformation and enlargement in kindergartens Bajka, Kolibri and Plavi čuperak. Source: author

\section{CONCLUSION}

The educational development strategy in Serbia up to 2020 brings out the necessity to initiate modern, cuttingedge educational programs at an early age. The interior design and decoration of day care space, as a space where children spend most of their time, is especially important. The importance of investment into early education, and thereby the society itself, is already confirmed by the successful models of educational systems applied in Scandinavian countries. Innovative educational methods are constantly developing, sharing a primary aim of respecting children's needs and stimulating various individual potentials. The analysis of the interactive educational method identified a connection between the needs of children of certain age and the space they inhabit. In the process of applying the interactive educational method, children's social behaviour and their relationship towards the physical environment are influenced primarily by the functional organization of space. Interactive space should have fundamental and developmental characteristics which would serve as a foundation for the application of the interactive educational method.

Creating a healthy environment for pre-school children in kindergartens is about providing fundamental spatial comfort, a comprehensive program and conceptual adaptation of both inner and outer space. The main methods used in this study were the comparative analysis of the existing conditions and recommended norms, as well as analysis of the possibilities for implementation of principles of interactivity. The paper further explores the relationship between the present features and the application of interactive educational methods of instruction which suit various psycho-social propensities of preschool children. In that context, the main scientific contribution of this research is: identification of existing issues and recommendations for further interventions that will eventually improve the existing condition. The most important problems recognized in the analysed kindergartens are: insufficient size of the courtyard (very rare, but significant problem), standardized types of playrooms that do not encourage interaction, and conservative roles of multipurpose spaces.

The recommended solution for the overload of the site area by the kindergarten buildings is introduction of open green roofs that would compensate lack of playground area. The majority of the important changes in kindergarten architecture take place in the interior design. Therefore, new kindergarten design should promote the spatial environment that cater diverse types of learning from active to calm spaces and from dynamic group spaces to more individual. Many existing classrooms are simply not designed to meet the developmental needs of infants and toddlers in group care, nor do they support teachers in their role as facilitators of children's learning and self-directed play. On the other hand, a well-designed environment can have an enormous, positive impact on the well-being of both children and teachers. Therefore, horizontal (creating of activity pockets using mobile elements and custommade furniture) and vertical (introduction of galleries for sleeping) spatial differentiation of existing playrooms is recommended as central activity. Finally, enlargement of multipurpose spaces, and putting these spaces into central 
role in new kindergartens is equally important transformation, carefully analysed and described in previous chapters.

\section{Acknowledgements}

The paper was done within the scientific project "Revitalization of the Kindergartens in Serbia -Program and Methods for Improvements of Ambient, Functional and Energetic Quality", No TR36045 funded by Ministry of Education and Science, the Republic of Serbia.

\section{REFERENCES}

[1] Şahin, B. E. \& Dostoğlu, N. T. (2012). The importance of preschoolers' experience in kindergarten design. METU Journal of the Faculty of Architecture, 29(1), 301-320.

[2] Nolte, D. \& Harris, R. (1998). Children learn what they live. New York: Workman Publishing. (Book originally published in 1972, poem first publication on April $4^{\text {th }}, 1954$, in Torrance Herald, Torrance, California).

[3] Službeni Glasnik Republike Srbije, Education Strategija razvoja obrazovanja u Srbiji do 2020. godine. No. 107/2012, (2012.)

[4] Cirhinlioğlu, F. G. (2001). Çocuk Ruh Sağlığı ve Gelişimi: Okul Öncesi Dönem. Ankara: Nobel Yayın Dağıtım.

[5] Colić, V. (2013.) Ideje Aleksandre Marjanović o nauci i obrazovanju predškolskog deteta. Krugovi detinjstva, časopis za multidisciplinarna istraživanja detinjstva, 2, 8288.

[6] Maxwell, L. E. \& Evans, G. W. (2006). Community-Based Child Care Settings. Implications. The Web version 6, 1. http://rs.informedesign.org/_news/jan_v06r-p.pdf

[7] Tanić, M., Stanković, D., Kostić, I., Nikolić, V., Petrović, M., \& Kondić, S. (2016). Pedagogical Implications of the Concepts of the Classroom in Europe: The Key Historical Layers, Tendencies and Influential Lines. Journal of Asian Architecture and Building Engineering, 15(1), 1-8. https://doi.org/10.3130/jaabe.15.1

[8] Read, M. A. (2010), Contemplating Design: Listening to Children's Preferences about Classroom Design. Department of Design and Human Environment, Oregon State University, Corvallis, USA. https://doi.org/10.4236/ce.2010.12012

[9] Moore, G. The physical environment and cognitive development in child-care centers. Spaces for children: The built environment and child. New York: Springer US, 41-72. https://doi.org/10.1007/978-1-4684-5227-3_3

[10] Nikolić, M., Milojković, A., Stanković, D., Bogdanović, V., \& Mijailović, I. (2016). Implementation models for energy recovery measures of existing kindergarten facilities in Serbia. Tehnički vjesnik-Technical Gazette, 23(2), 437-446. https://doi.org/10.17559/TV-20131230163936

[11] Stanković, D. \& Tanić, M. (2014). Preschool Building in the Context of Interior Environment Revitalization. Revitalization of Preschool Facilities in Serbia, Niš. Faculty of Civil Engineering and Architecture, University of Niš, 23-42.

[12] Popović, A. (2007). Interaktivno učenje - inovativni način rada u nastavi, Stručni rad. Obrazovna tehnologija. Učiteljski fakultet, Univerzitet u Beogradu, Beograd.

[13] Dudek, M. (2005). The School Building as Third Teacher. In Dudek, M. (ed) Children's Spaces. Oxford: Architectural Press.

[14] Day, C. (2007). Environment and Children, Passive Lessons from the Everyday Environment. New York: Architectural Press.
[15] Tanic, M., Nikolic, V., Stankovic, D., Kondic, S., Zivkovic, M., Mitkovic, P., \& Kekovic, A. (2015). Interconnection between physical environment and pedagogical process in elementary schools in Niš. Current Science, 108(7), 12281234.

[16] Moore, G. T. (1985). The designed environment and cognitive development: A brief review of five domains of research. Children's Environments Quarterly, 5(3), 41-72. https://doi.org/10.1007/978-1-4684-5227-3_3

[17] Brodin, J. \& Lindstrand, P. (2006). Interaction in Outdoor Play Environments - Gender, Culture and Learning, Research Report $n r$ 47. Stockholm Institute of Education, Stockholm.

http://www.buv.su.se/polopoly_fs/1.44426.1320917347!/T $\mathrm{KH}$ 47.pdf

[18] Lazić, S. (2013). Konstruktivizam - paradigma predškolskog vaspitanja i obrazovanja 21 . veka. Razvojne karakteristike deteta predškolskog uzrasta, Zbornik radova, Novi Sad, 1929.

[19] Moore, G. T., Sugiyama, T., \& O'Donnell, L. (2003) The Children's Physical Environments Rating Scale. Children: The Core of Society, Proceedings of the Australian Early Childhood Association Biennial Conference (CD-ROM) Canberra.

[20] Stanković, D., Milojković, A., \& Tanić, M. (2006). Physical Environment Factors and their Impact on the Cognitive Process and Social Behaviour of Children in the Preschool Facilities. Facta Universitatis - series: Architecture and Civil Engineering, 4(1), 51-57. https://doi.org/10.2298/FUACE0601051S

[21] Ivanović-Šekularac， J. (2000). Predškolske ustanove $i$ komfor. Beograd: Zadužbina Andrejević.

[22] Pravilnik o bližim uslovima za početak rada I obavljanje delatnosti ustanova za decu (1994) in Službeni glasnik RS 50/94 I 6/96.

[23] Moore, G. T. (1986). Effects of the spatial definition of behaviour settings on children's behaviour: A quasiexperimental field study. Journal of Environmental Psychology, 6, 205-231.

https://doi.org/10.1016/S0272-4944(86)80023-8

\section{Contact information:}

Aleksandar MILOJKOVIĆ, Assistant Professor, PhD

(Corresponding author)

Faculty of Civil Engineering and Architecture, University of Niš,

Aleksandra Medvedeva 14, 18000 Niš, Serbia

aleksandar.milojkovic@gaf.ni.ac.rs

Jasmina TAMBURIĆ, Teaching and Research Assistant, MSc Faculty of Civil Engineering and Architecture, University of Niš Aleksandra Medvedeva 14, 18000 Niš, Serbia ministo@yahoo.com

Danica STANKOVIĆ, Associate Professor, PhD

Faculty of Civil Engineering and Architecture, University of Niš Aleksandra Medvedeva 14, 18000 Niš, Serbia danica.stankovic@gaf.ni.ac.rs

Milan BRZAKOVIĆ, PhD student, MSc

Faculty of Civil Engineering and Architecture, University of Niš, Aleksandra Medvedeva 14, 18000 Niš, Serbia milan.b23@hotmail.com 